\title{
Studies of 'Rind Yellow Spot', a Physiological Disorder of Naruto (Citrus medioglobosa Hort. ex TANAKA)- Low Temperature and Ethylene Evolution from Injured Fruits
}

\author{
Takao Ichil and Kenichi Hamada \\ Faculty of Agriculture, Kobe University, Kobe and Agricultural \\ Experiment Station of Hyogo Prefecture, Sumoto
}

\begin{abstract}
Summary
Rind yellow spot, a physiological disorder of Naruto (Citrus medioglobosa Hort. ex TANAKA), usually appears at late January, increases rapidly from February to mid-March, and symptoms do not develop after late March. Thus, the period of occurrence seems to be associated with low temperatures during the winter. Affected fruits produced a much higher amount of ethylene compared to healthy fruits when picked before late March, while those picked after that did not. However, when the latter were subjected to a temperature of $5^{\circ} \mathrm{C}$ and transferred to $20^{\circ} \mathrm{C}$, there was an increase in the rate of ethylene production in response to the low temperatures. Peak rates were repeated upon transfer from $5^{\circ} \mathrm{C}$ to $20^{\circ} \mathrm{C}$. These results suggest that low temperatures, possibly along with diurnal changes of temperature in winter, are involved in the development of the disorder.
\end{abstract}

\section{Introduction}

Rind yellow spot, a physiological rind disorder of Naruto (Citrus medioglobosa Hort. $e x$ TANAKA), which has recently been discovered is a serious problem affecting commercial production in Awaji island, Hyogo Prefecture. Although the real cause of the disorder has not yet been clarified, it is a rind injury associated with fruit maturation (6).

Evidence of the disorder is not detected usually until late January when the temperature has dropped, and symptoms do not develop after late March, following the rise in temperatures. This suggests that the low temperature during the winter period is involved in the development of the disorder. Cooper et al (4) have shown that chilling enhances ethylene production in citrus fruits and suggested the involvement of such chilling-induced ethylene in the loss of green color. This paper is concerned with the physiological response of injured fruits to chilling as related to ethylene production.

Received for publication March 24, 1977

\section{Materials and Methods}

Fruits used in this study were obtained from the Naruto orchards in Tsunacho, main 1y in the year 1975-1976. Healthy and aff ected fruits were collected both before and afte $r$ late March, that is to say from the periods when the disorder occurs or does not occur, respectively. The freshly harvested fruits were tested for ethylene evolution. For fruits sampled after late March, ethylene determination was also made after exposure of the fruits tct temperatures of $5^{\circ} \mathrm{C}$ and $20^{\circ} \mathrm{C}$ for $10-20$ days. During the periods of exposure fruits were kept in plyethylene bags to prevent from drying. Affected fruits with secondary symptoms such as browning etc. were avoided. After sterilization with $1 \%$ sodium hypochloride, 3 fruits from each sample were kep $t$ in a sealed $2500 \mathrm{~m} l$ jar at $20^{\circ} \mathrm{C}$ for 4 hours, except as noted otherwise. Two $\mathrm{m} l$ sample of gas was taken from each jar and measured the ethylene content by gas chromatographs. In order to see the effect of desiccation on ethylene production, fruits were kept in a desiccating cabinet over silica gel at $5^{\circ} \mathrm{C}$ for a week 
before the ethylene was measured. For determining the ethylene evolution from rind disks, 20 disks were cut out from the rinds with a $9 \mathrm{~mm}$ diameter cork borer, and placed in a sealed $60 \mathrm{ml}$ glass tube with moist filter paper at $20^{\circ} \mathrm{C}$ for 4 hours. One $\mathrm{m} l$ sample of gas was taken and measured the ethylene content by gas chromatography.

\section{Results}

\section{Ethylene evolution from fruits}

(1) Fruits taken before late March

Healthy fruits and affected fruits with moderate to severe symptoms were collected on February 23, 1972. Seven fruits from each

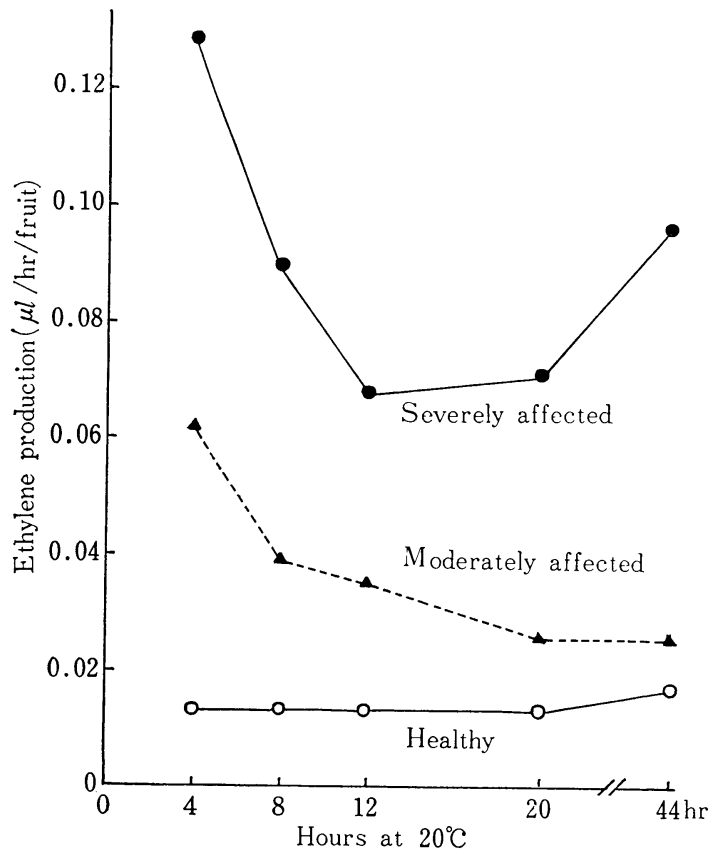

Fig. 1. Ethylene production of healthy and affected fruits. Fruits were collected on February 23, 1972. Ethylene determination was made at $20^{\circ} \mathrm{C}$ on freshly harvested fruits. sample were placed in a sealed $5500 \mathrm{ml}$ jar in order to determine ethylene production. No replications were made. The results are shown in Figure 1. While the healthy fruits evolved less than $0.02 \mu l / h r$ per fruit of the ethylene, the affected fruits produced it 3 times or more, the quantity being related to the severity of the injury. A peak rate of ethylene evolution from the affected fruits was attained during the first 4 hours of the incubation period and the rate subsequently decreased with time. But, the severely affected fruits showed a tendency to increase production of ethylene again 20 hours after incubation. A similar experiment was repeated for the fruits collected on March 11, 1976, using 3 fruits in a sealed jar. Four and 6 replications were made for the healthy and affected fruits, respectively. Peaks of ethylene production emerged at 4 to 12 hours, depending upon the replication. It is clear that affected fruits produced more ethylene than did healthy fruits (Table 1).

(2) Fruits taken after late March

Figure 2 a shows the ethylene production of the healthy and affected fruits collected on April 8, 1975. The affected fruits produced very little of ethylene. Thus, little difference could be noted in the rate of ethylene production between the affected and healthy fruits. The fruits collected on April 30, 1976 produced essentially the same results (Table 1 ). However, when fruits were kept at $5^{\circ} \mathrm{C}$ for periods from 15 to 18 days and then transfered to $20^{\circ} \mathrm{C}$, the affected fruits produced substantially higher amounts of ethylene than did the healthy fruits (Figure $2 \mathrm{~b}$ and $\mathrm{c}$ ). Peaks of ethylene production appeared in 8 to 12 hours after transfer of the fruits to $20^{\circ} \mathrm{C}$ and the increased ethylene levels persisted for 2 to 3 days. After the first peak of ethylene production, one lot

Table 1. Ethylene production of healthy and affected fruits collected before and after late March (1976)

\begin{tabular}{l|c|c|c|c|c|c|c|c|c|c}
\hline & \multicolumn{3}{|c|}{ Hours at $20^{\circ} \mathrm{C}$ (Sampled on Mar. 11) } & \multicolumn{3}{|c|}{ Hours at 20 C (Sampled on Apr. 30) } \\
\cline { 2 - 8 } & 4 & 8 & 12 & 16 & 44 & & 5 & 10 & 14 & 18 \\
\hline Healthy & 0.003 & 0.005 & 0.007 & 0.005 & 0.006 & Healthy & 0.007 & 0.009 & 0.008 & 0.009 \\
Affected & 0.022 & 0.023 & 0.020 & 0.019 & 0.018 & Affected & 0.008 & 0.009 & 0.009 & 0.010 \\
Significance & $*$ & $* *$ & $* *$ & $* *$ & $* *$ & Significance & N S & N S & N S & N S \\
\hline
\end{tabular}

Rate of ethylene production is expressed as $\mu \mathrm{l} / \mathrm{hr} / \mathrm{fruit}$. Three and 6 replications with 3 fruits for healthy and affected fruits, respectively.

* Significant at $5 \%$ level. ** Significant at $1 \%$ level. 


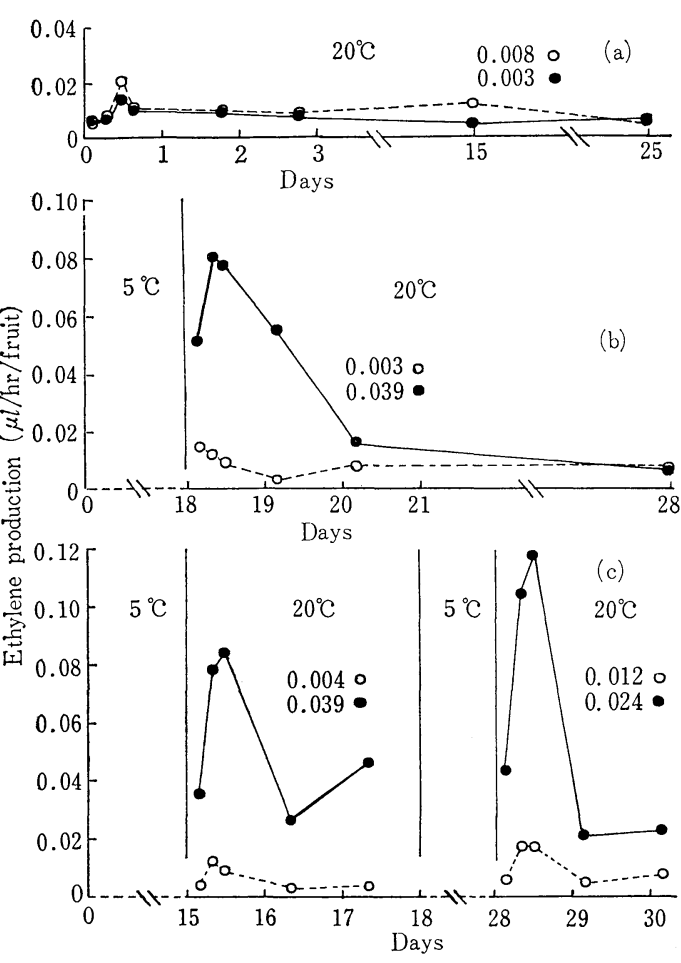

Fig. 2. Ethylene production of healthy (O) and affected $(\bullet)$ fruits. Fruits were collected on April 8, 1975. Ethylene determination were made at $20^{\circ} \mathrm{C}$ on freshly harvested fruits and after exposures of fruits to $5^{\circ} \mathrm{C}$ for $10 \sim 20$ days. The confidence limits are presented in figures.

of fruits was placed in storage at $5^{\circ} \mathrm{C}$, while the other lot remained at $20^{\circ} \mathrm{C}$. Again, a second peak was observed for the affected fruits exposed to $5^{\circ} \mathrm{C}$ for 10 days and then transfered at $20^{\circ} \mathrm{C}$ (Figure $2 \mathrm{c}$ ), but this was not the case for those kept constantly at $20^{\circ} \mathrm{C}$ (Figure $2 \mathrm{~b}$ ). These findings demonstrate that low temperature may cause ethylene evolution from affected fruits. Figure $2 \mathrm{c}$ shows that the second peak of ethylene production might be high compared to the first. Similar results were obtained for the fruits collected on April 15 , 1976, viz $0.056 \pm 0.016$ and $0.145 \pm 0.038$ $\mu l / \mathrm{hr}$ per fruit, for the first and second peaks, respectively. Thus, it is likely that frequent exposure to low temperatures results in progressively high ethylene production.

(3) Effect of desiccation on ethylene evolution

In order to test the possibility that desiccation might enhance ethylene evolution from affected fruits, fruits which were sampled on
Table 2. Effect of desiccation on ethylene evolution from affected fruits (Sampled on 30 th 4 pril 1976)

\begin{tabular}{|c|c|c|c|c|c|}
\hline & \multicolumn{5}{|c|}{ Hours at $20^{\circ} \mathrm{C}$} \\
\hline & 5 & 8 & 12 & 30 & 55 \\
\hline At $5^{\circ} \mathrm{C}$ for 19 days & 0.048 & 0.067 & 0.055 & 0.012 & 0.024 \\
\hline $\begin{array}{l}\text { At } 5^{\circ} \mathrm{C} \text { for } 12 \text { days }+ \\
\text { at } 5^{\circ} \mathrm{C} \text { and reduced } \\
\text { humidity for } 7 \text { days }\end{array}$ & 0.043 & 0.058 & 0.023 & 0.014 & 0.051 \\
\hline
\end{tabular}

April 30, 1976 were kept at $5^{\circ} \mathrm{C}$ under dry conditions for a week. As shown in Tatile 2, there was no further increase in ethylene production as a result of the dry treatinent. Fresh weights of fruits were reduced to 99.4 and $98.1 \%$ (significant at $5 \%$ level) of the initial weights for the control and the dry treatment, respectively.

\section{Ethylene evolution from rind disks}

Ethylene production in rind disks pre pared from tissue of healthy fruits and from both sound and affected tissues of affected fruits was measured. Ethylene production in rind disks increased with time, at the highest in the affected tissue, at the next highest in the sound tissue of the affected fruits and fonally at the lowest in the tissue of the healthy fruits (Figure 3).

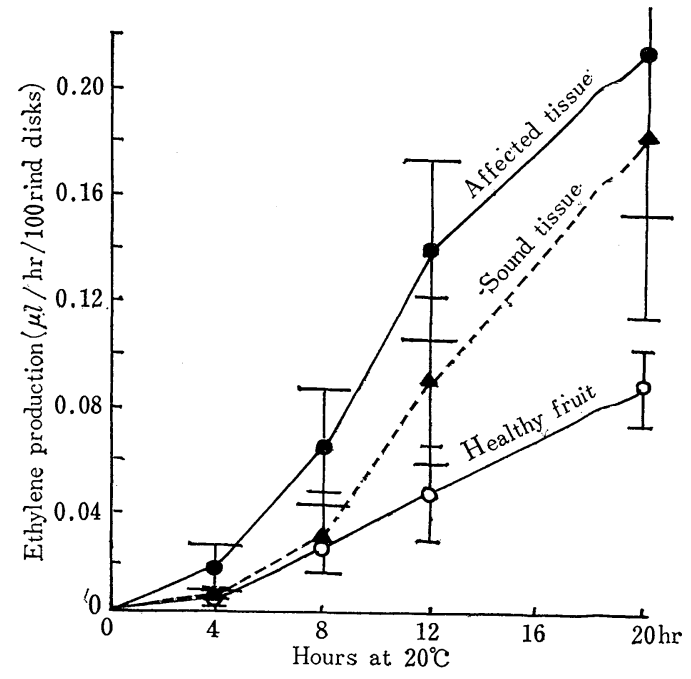

Fig. 3. Time course of ethylene production in rind disks.

Disks were prepared from tissue of healthy fruits, and from both sound and affected tissues of affected fruits. Vertical lines represent the confidence limits. 


\section{Discussion}

Changes of pentad mean maximum and minimum air temperatures during the last 10 years in Sumoto, Awaji island are shown in Figure 4. Naruto rind color begins to change from late October into early November and becomes yellow orange in December, and orange in February. Thus, the orange color develops on the rinds as the minimum temperatures drop below $5^{\circ} \mathrm{C}$. Cooper et al (4) showed that the rind color of the Pineapple orange turned rapidly from green to orange in late October following the cool nights $\left(5^{\circ} \mathrm{C}\right)$. Naruto rind yellow spot usually appears after late January and increases rapidly between early February and mid-March. After late March, the disorder is eliminated or the fruits recover. Therefore, occurrence may be closely associated with minimum temperatures below $5^{\circ} \mathrm{C}$ (Figure 4). In fruits collected at this period, while the amount of ethylene produced by healthy fruits was small (ca. $0.02-0.08 \mu \mathrm{l} / \mathrm{hr}$ / $\mathrm{kg}$ ), the amount produced by affected fruits was much greater. On the contrary, when the fruits were collected after late March when the minimum temperature is above $5^{\circ} \mathrm{C}$, the affected fruits produced only a small amount of ethylene. However, exposure to $5^{\circ} \mathrm{C}$ caused affected fruits to produce substantial amount of ethylene. Tnese findings indicate that ethyl- ene production above the normal amount $(2,3)$ in affected fruits could be caused by low temperatures in winter. Ethylene in such high amounts is considered to be a product of the disorder (10), suggesting that low temperature is involved in its development. Ethylene released from the injured fruits, in turn, might be partially responsible for development of the disorder, because ethephon treatment increased it (6). Iwata et al (7) have shown that an injury similar to chilling symptoms develops in Natsudaidai fruits at $43^{\circ} \mathrm{F}$, a safe storage temperature, by exposure to ethylene gas. Although low temperature may be involved in development of the disorder, it is different from the chilling injury of citrus fruits which has caused great concern as a storage disorder (8). Rind yellow spot develops on the rinds while on the tree and does not necessarily follow pitting or browning which are known as characteristics of chilling injury.

The incidence is severe in warm areas or warm years during the winter period. It occurs most frequently on well-colored fruits exposed to the sun (6). Further, a high incidence has been observed on fruits grown under glasshouse conditions with a high maximum and nearly equal minimum temperature compared to that of the field (5). Several items of evidence indicate the possible involvement of maximum temperature, associated

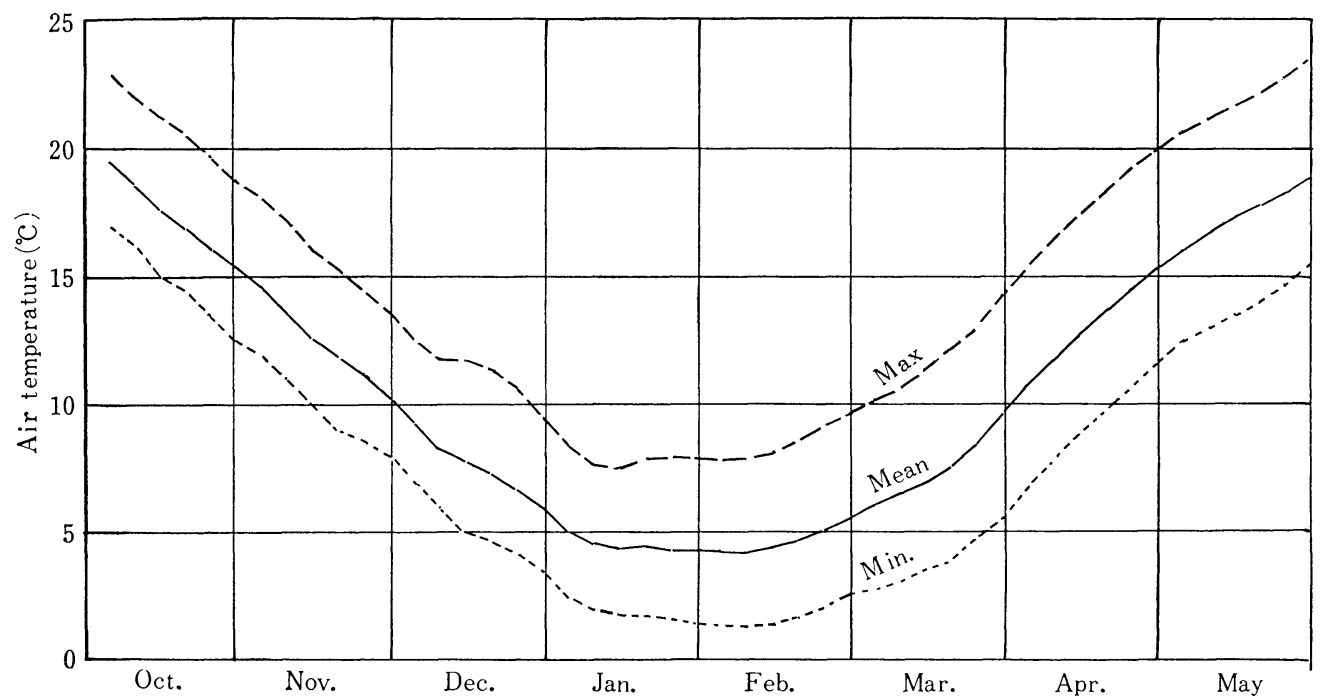

Fig. 4. Mean pentad maximum and minimum air temperatures during recent 10 years at Sumoto in Awaji island. 
with minimum temperature, in development of the disorder. The unfavorable effect of high maximum temperatures on the disorder is a stimulation of fruit maturation. Such fruits are exposed more frequently to low temperatures below $5^{\circ} \mathrm{C}$ for the subsequent maturation period, hence being more subject to the disorder. This can be understood, if it is assumed that the fruit becomes susceptible to low temperature effects as the fruit mature. Chilled affected fruits repeated peaks of ethylene production upon transfer from $5^{\circ} \mathrm{C}$ to $20^{\circ} \mathrm{C}$ (Figure $2 \mathrm{c}$ ), which suggests that diurnal changes of air temperature in the winter period stimulate ethylene production. Thus, another unfavorable effect of high maximum temperatures may be an enhancement of ethylene production.

Adato and Gazit (1) have demonstrated that water deficit can enhance ethylene production in avocado fruits. In the present experiment, there was no measurable water loss from the fruits during storage at $5^{\circ} \mathrm{C}$ in polyethylene bags, and the desiccation treatment caused no further enhancement of ethylene production.

Riov et al (9) showed that flavedo disks cut from mature grapefruit produced increasing amounts of ethylene with time. The present experiment showed similar results in which the rind disks from the affected fruits, even though prepared from sound tissue, produced higher amounts of ethylene than did those from healthy fruits. Thus, some physiological changes are likely to precede the anatomical abnormalities which can be stained with phloroglucinol- $\mathrm{HCl}(6)$.
Since ethylene production is considered to be the result of deteriolation of tissues, further study is necessary to elucidate its cause.

\section{Literature Cited}

1. AdATO, I. and S. GaziT. 1974. Water deficit stress, ethylene production and ripening in avocado fruits. P1. Physiol. $53:$ 45-46.

2. BEN-YEHOSHUA, S. and I. L. EARKS. 1970. Ethylene production and abscission of fruit and leaves of orange. Bot. Gaz. 131: 144150.

3. BURG, S.P. and E. A. BURG. 1965. Ethylene action and the ripening of fruits. Science. $148: 1190-1196$.

4. COOPER, W.C., G. K. RASMUSSEN and E. S. WALDON: 1969. Ethylene evolution stimulated by chilling in Citrus and Persea sp. Pl. Physiol. $44: 1194-1196$

5. HAMADA, K., T. TANIGUCHI and T. UEOKA. 1973. Hyogo Agr. Expt. Sta. Bul. $20: 19-22$.

6. ICHII, T. and K. HAMADA. 1978. Studies of 'rind yellow spot', a physiological disorder of Naruto (Citrus medioglobosa Hort. ex Tanaka) J. Jap. Soc. Hort. Sci. $46: 442-448$.

7. IWATA, T., K. NAKAGAWA and K. OGata. 1969. Physiological studies of chilling injury in Natsudaidai (Citrus natsudaidai Hayata) fruits. II J. Jap. Soc. Hort. Sci. $38: 93$.

8. LYONS, J. M. 1973. Chilling injury in plants. Ann. Rev. Plant Physiol. 24 : 445-466.

9. RIOV, J., S.P. MONSLISE and R.S. KAHAN. 1969. Ethylene-controlled induction of phenylalanin ammonia-1yase in citrus fruit peel. Pl. Physiol. 44:631-635.

10. VINES, H. M., W. GRIERSON and G. J. EDW ARDS. 1968. Respiration, internal atmosphere and ethylene evolution of citrus fruit. Amer. Soc. Hort. Sci., Proc. 92 : 227-234. 


\author{
低温によるナルトミカンの生理障害 (果皮黄斑症) 果からの \\ エチレンの発生について \\ 一井隆夫・浜田憲一 \\ (神戸大学農学部・兵庫農総七淡路分場)
}

\begin{abstract}
摘 要
ナルトミカンの果皮黄坟症は 1 月下旬ごろから現わ . れ, 2 月下旬 $~ 3$ 月中旬に発生が多い, 3 月下旬以後は 新たな発生や症状の進展はみられない, 従って, 発生や 進展には冬季の低温が関係しているょうに思われる３ 月下旬以前に採取した障害果からは, 健全果に比し多量 のエチレンの発生がみられた. これに対し, それ以後に

った. しかし， 3 月下旬以後の採取果を一定期間 $5^{\circ} \mathrm{C} に$ 置き, $20^{\circ} \mathrm{C}$ に移すと, 障害果からはエチンン発生のピ ークが認められた. ピークは低温に感応させることによ って再び現われた. 従って, 果皮黄斑症の発生または進 展には, 1 つの要因として冬季の低温が関係し, 低温と 高温の繰返しがそれを助長しているものと思われる.
\end{abstract} 採取した障害果では, その発生は健全果同様わずかであ 